\title{
Serum HER-2 concentrations for monitoring women with breast cancer in a routine oncology setting
}

\author{
Patricia Diana Sørensen ${ }^{1, *}$, Erik Hugger \\ Jakobsen ${ }^{2}$, Sven Tyge Langkjer², Susanne \\ Bokmand $^{3}$, Birthe Østergaard ${ }^{4}$, Dorte Aalund \\ Olsen ${ }^{1}$, Jonna Skov Madsen ${ }^{1}$ and Ivan \\ Brandslund ${ }^{1}$ \\ ${ }^{1}$ Department of Clinical Biochemistry, Lillebaelt \\ Hospital, Vejle, Denmark \\ ${ }^{2}$ Department of Oncology, Lillebaelt Hospital, Vejle, \\ Denmark \\ ${ }^{3}$ The Mamma Center, Lillebaelt Hospital, Vejle, \\ Denmark \\ ${ }^{4}$ Department of Pathology, Lillebaelt Hospital, Vejle, \\ Denmark
}

\begin{abstract}
Background: The purpose of this study was to determine the positive predictive value (PPV) of positive serum human epidermal growth factor receptor-2 (HER-2) for monitoring women with breast cancer following diagnosis and treatment in a routine clinical setting.
\end{abstract}

Methods: Serum HER-2 was measured in 1348 patients with breast cancer: 837 during routine oncology clinic visits and 511 following new diagnosis. All patients with positive serum HER-2, 1/5 of negative patients from the oncology clinic, and all the newly diagnosed were followed; a total of 862 patients. Serum HER-2 was measured using the Bayer ADVIA Centaur assay. Tissue HER-2 was determined using immunohistochemistry (IHC) and fluorescence in situ hybridization (FISH). IHC +3 or $\mathrm{IHC}+2$ and $\mathrm{FISH}>2.0$ were positive. Patients were considered to have positive serum HER-2 when at least two values were $>15 \mathrm{ng} / \mathrm{mL}$. Recurrence, progression and regression were diagnosed according to usual clinical practice. Serum HER-2 concentrations did not contribute to diagnostic decision-making or selection of treatment. Results: From January 2004 to January 2009, 149 patients were found to have positive serum HER-2. Of these, 35 were tissue HER-2 positive at surgery, 69 tissue-negative and 45 were not determined. Fifty-five of 149 that were serum HER-2 positive $(37 \%, 95 \% \mathrm{Cl}$ : 29-45) had metastases. Among the 35 tissue-positive patients, 25 had recurrence in the form of metastases and there was good correlation between recurrence/ progression and increase in serum HER-2 ( $p<0.0003)$. There was also a high correlation between effect of

*Corresponding author: Patricia Diana Sørensen, Department of Clinical Biochemistry, Lillebaelt Hospital, Kabbeltoft 25, 7100 Vejle, Denmark

E-mail: Patricia.Diana.Soerensen@slb.regionsyddanmark.dk Received March 1, 2009; accepted June 16, 2009 treatment and decline in serum HER-2 ( $p<0.0003)$. Of the 69 tissue-negative patients, 29 had recurrence in the form of metastases, and there was good correlation with serum HER-2 levels $(p<0.000004)$. In this routine application of serum HER-2, the PPV for metastases recurrence detection in both tissue-positive and tissue-negative was 54 of $104(52 \%, 95 \% \mathrm{Cl}$ : $42 \%-62 \%)$, in tissue-positive 25 of $35(71 \%, 95 \% \mathrm{Cl}$ : $54 \%-85 \%)$, in tissue-negative 29 of 69 (42\%, 95\% Cl: $30 \%-54 \%)$. The lead time of increases in serum HER2 before recurrence could be determined in ten tissuepositive patients was 3-24 months (mean 11.3 months), when compared to standard clinical imaging methods.

Conclusions: Serum HER-2 is a useful marker for the detection of recurrence of breast cancer and for monitoring the effect of treatment, especially in tissue HER-2 positive patients.

Clin Chem Lab Med 2009;47:1117-23.

Keywords: breast cancer; breast tissue; metastases; progression; recurrence; regression; serum human epidermal growth factor receptor-2 (HER-2).

\section{Introduction}

The human epidermal growth factor receptor-2 (HER2)/neu gene encodes a transmembrane glycoprotein with tyrosine kinase activity. This glycoprotein mediates proliferation and differentiation in both normal and cancer cells.

In $20 \%-25 \%$ of patients with breast cancer, the gene is amplified and detectable by fluorescence in situ hybridization (FISH). This results in higher than normal HER-2 receptor protein concentrations in the tissue that is detectable by both immunohistochemistry (IHC) and protein quantitation by ELISA (1).

HER-2 gene amplification and/or over expression is associated with poor prognosis (2).

Tissue HER-2 status is commonly determined by $\mathrm{IHC}$ and $\mathrm{FISH}$, where $\mathrm{IHC}+3$ or $\mathrm{IHC}+2$ and $\mathrm{FISH}>2.0$ are considered positive.

It is known that the HER-2 extracellular domain (ECD) may be cleaved and shed from the surface of breast cancer cells and released into the circulation (3).

Circulating concentrations of HER-2 ECD can be measured in serum. While determination of tissue HER-2 is a one-time event, serum HER-2 can be measured any time during follow-up.

The serum HER-2 test using the ADVIA Centaur assay is approved by the Food and Drug Administration (FDA) for follow-up and monitoring of patients 
with metastatic breast cancer (MBC) whose initial serum HER-2 concentration is above $15 \mathrm{ng} / \mathrm{mL}$ (4).

The purpose of this study was to determine the positive predictive value (PPV) of positive serum HER-2 in monitoring women with breast cancer following diagnosis and treatment.

\section{Materials and methods}

\section{Study population}

The Regional Science Ethics Committee of Fyns and Vejle Counties (reg. nr S-VF-20040101) approved the work. Between January 2004 and January 2009, serum HER-2 was measured in 1348 patients with breast cancer: 837 during routine oncology clinic visits and 511 patients that were newly diagnosed. We followed all serum-positive HER-2 patients (above $15 \mathrm{ng} / \mathrm{mL}$ ), 1/5 of the serum-negative patients from the oncology clinic and all of the newly diagnosed patients $(n=862)$. Patients with only one serum HER-2 measurement were excluded.

All newly diagnosed and treated patients were followed after surgery with serum HER-2 at clinically determined time intervals (3-12-month intervals). Serum HER-2 concentrations did not contribute to diagnostic decision-making or treatment.

\section{Clinical follow-up and anticancer treatment}

Following primary breast cancer surgery, patients were followed routinely for relapse by physical examination. If the patient presented with symptoms of relapse, MR/CT/UL (Magnetic Resonance Imaging/Computed Tomography/ Ultrasound) and X-ray examination were performed. Measurable and non-measurable disease was documented. Solitary lesions were verified cytologically and/or histologically if they indicated the only evidence of disease. A scaled photograph of skin metastases was taken. Patients with histologically confirmed HER-2 positive (IHC3+ or FISH+), locally advanced or MBC were treated with chemotherapy, including use of Trastuzumab. Due to the high response rates found in the phase II study when using a combination of either Vinorelbine and Trastuzumab or the Taxanes and Trastuzumab, these regimes were used as first and second line treatments. The following treatment was used: Trastuzumab $6 \mathrm{mg} / \mathrm{kg}$ every 3 weeks by intravenous (IV) infusion over $90 \mathrm{~min}$. Initial dose was $8 \mathrm{mg} / \mathrm{kg}$ (loading dose). For Docetaxel, $100 \mathrm{mg} / \mathrm{m}^{2}$ every 3 weeks IV infusion over $60 \mathrm{~min}$. For Vinorelbine, $30 \mathrm{mg} / \mathrm{m}^{2}$ IV infusion over $10 \mathrm{~min}$ day 1 , and $8 \mathrm{mg} / \mathrm{m}^{2}$ every 3 weeks. A few patients with extensive liver metastases were treated with Trastuzumab and a weekly dose of Paclitaxel $\left(80 \mathrm{mg} / \mathrm{m}^{2}\right)$. Third line treatment was Lapatinib-Capecitabine with doses of $1250 \mathrm{mg}$ Lapatinib and Capecitabine at a dose of $1000 \mathrm{mg} / \mathrm{m}^{2}$ per os (PO) days $1-14$, every 21 days. Many of the younger patients received adjuvant chemotherapy with Antracycline [FEC or EC (Fluorouracil, Epirubicin, Cyclophosphamide or Epirubicin, Cyclophosphamide)].

For patients with HER-2 negative disease, first line chemotherapy consisted of Docetaxel. If patients had received adjuvant Antracycline previously, Capecitabine was used as second line treatment.

\section{Evaluation of response}

Measurable disease was evaluated according to response evaluation criteria in solid tumors (RECIST) $(5,6)$. All lesions found at the time of relapse were recorded and followed using the same methods. Lesions were evaluated by physical examination (palpable lymph nodes, or skin metastases) and by MR, CT scanning and X-ray examinations. These were reviewed every 9 th week until progression. Complete response (CR) or partial response (PR) was confirmed after at least 4 weeks.

\section{Biochemical analysis}

Serum HER-2 was measured using the Bayer Advia Centaur, XP Immunoassay System Bayer Health Care (Siemens Medical Solutions Diagnostics, Ballerup, Denmark). In brief, the ADVIA Centaur HER-2 assay is an automated sandwich immunoassay using direct chemiluminescent technology (1).

$\mathrm{CV} \%$ in the period was measured using commercial and in-house control materials at 8,14 and $113 \mathrm{ng} / \mathrm{mL}$. The CVs were $6.6,4.6$ and $4.8 \%$, respectively. Tissue HER-2 was determined using IHC and FISH. In brief, IHC was performed on formalin-fixed, paraffin-embedded breast tissue sections using the Hercep Test (DakoCytomation, Glostrup, Denmark). FISH was performed on formalin-fixed, paraffinembedded breast tissue sections using a HER-2 FISH pharmDx kit (DakoCytomation) (1). IHC +3 or $\mathrm{IHC}+2$ and $\mathrm{FISH}>2.0$ was considered positive.

\section{Data analysis}

Patients were considered to have positive serum HER-2 when at least two values were $>15 \mathrm{ng} / \mathrm{mL}$. One value above $15 \mathrm{ng} / \mathrm{mL}$ did not accelerate control visits. Recurrence, progression and regression were diagnosed according to usual clinical practices as described above. PR and CR were registered together as response.

The Mann-Whitney test was used to evaluate statistically significant differences. We used the NCSS 2004 statistical package (Number Cruncher Statistical System, Kaysville, Utah, USA). Predictive values were calculated according to "Evaluation of test data from clinical studies" according to Gerhardt and Keller (7).

\section{Results}

Of the 862 patients, 219 had not been characterized by tissue HER-2 test at the time of surgery, 437 were tissue HER-2 negative and 206 were tissue HER-2 positive (IHC $3+$, or IHC $2+$ and $\mathrm{FISH}>2$ ).

Serum HER-2 was positive in 149 of the 862 patients $(17.2 \%)$

Of the 206 tissue-positive patients, 35 were serum HER-2 positive during the period (16.9\%). Of the 437 tissue-negative patients, 69 were serum HER-2 positive during the period (15.7\%). Of the 219 patients whose tissue status was unknown, 45 were serum HER-2 positive during the period (20.5\%) (Table 1).

Of the 149 patients with positive serum HER-2, only 35 were tissue-positive, 69 were tissue-negative and 45 were of unknown tissue status (Table 2). Patient demographics and tumor characteristics of the study population are shown in Table 3.

Figure 1 shows the highest values reached in IHC negative and positive patients. Higher concentrations were obtained in tissue-positive patients $(p<0.0000001)$. 
Figure 2 shows the highest values in tissue-negative patients, with or without relapse in the form of metastases $(p<0.000004)$. PPV at $>15 \mathrm{ng} / \mathrm{mL}$ was $29 / 69=42 \%$. A PPV of $100 \%$ was reached at a discrimination level of $25 \mathrm{ng} / \mathrm{mL}$, incorrectly classifying 11 of 29 with relapse (total false negatives $11 / 29=38 \%$ ).

Figure 3 shows the highest values obtained in tissue-positive patients with or without relapse in the

Table 1 All patients.

\begin{tabular}{lcccc}
\hline & $\begin{array}{l}\text { Tissue- } \\
\text { positive }\end{array}$ & $\begin{array}{l}\text { Tissue- } \\
\text { negative }\end{array}$ & $\begin{array}{l}\text { Unknown } \\
\text { tissue status }\end{array}$ & Total \\
\hline $\begin{array}{l}\text { Positive serum } \\
\text { HER-2 }\end{array}$ & 35 & 69 & 45 & 149 \\
$\begin{array}{l}\text { Negative serum } \\
\text { HER-2 }\end{array}$ & 171 & 368 & 174 & 713 \\
Total & 206 & 437 & 219 & 862 \\
\hline
\end{tabular}

HER-2, human epidermal growth factor receptor-2.

Table 2 Patients with increased serum HER-2.

\begin{tabular}{lllll}
\hline & $\begin{array}{l}\text { Tissue- } \\
\text { positive }\end{array}$ & $\begin{array}{l}\text { Tissue- } \\
\text { negative }\end{array}$ & $\begin{array}{l}\text { Unknown } \\
\text { tissue status }\end{array}$ & Total \\
\hline With relapse & 25 & 29 & 1 & \\
Without relapse & 10 & 40 & 44 & \\
Total & 35 & 69 & 45 & 149 \\
\hline
\end{tabular}

Table 3 Patient demographics and tumor characteristics of the study population.

\begin{tabular}{lc}
\hline & Total number \\
& $\mathrm{n}=149$ \\
\hline Age, years & \\
$\leq 40$ & 7 \\
$41-50$ & 22 \\
$51-60$ & 41 \\
$61-70$ & 49 \\
$\geq 70$ & 30 \\
Tumor size pathological T-measurement & \\
T1 & 41 \\
T2 & 70 \\
T3 & 10 \\
T4 & 12 \\
Tx & 16 \\
Number positive nodes (n-staging) & \\
N0 & 43 \\
N1mi & 8 \\
N1 & 46 \\
N2 & 15 \\
N3 & 18 \\
Nx & 19 \\
Histological type & \\
Invasive ductal carcinoma & 119 \\
Invasive lobular carcinoma & 6 \\
Other & 8 \\
Unknown & 16 \\
Estrogen receptor status & \\
Negative & 37 \\
Positive & \\
Unknown & \\
Progesterone receptor status & 38 \\
Negative & 67 \\
Positive & 44 \\
Unknown & \\
\hline & \\
\hline & \\
& \\
&
\end{tabular}

form of metastases $(p<0.00003)$. PPV at $>15 \mathrm{ng} / \mathrm{mL}$ was $25 / 35=71 \%$. Thus, the predictive value of serum HER-2 is higher in tissue-positive compared with tissue-negative patients, $71 \%$ against $42 \%(p<0.008)$.

A PPV of $100 \%$ was achieved at $32 \mathrm{ng} / \mathrm{mL}$, five patients were incorrectly classified with $5 / 25$ false negatives (20\%).

Figure 4 shows the increases in delta values in tissue-positive patients, with and without metastases $(p<0.0003)$. The PPV of $100 \%$ corresponds to a discrimination concentration of delta $16 \mathrm{ng} / \mathrm{mL}$, incorrectly classifying 7 of 25 patients that developed metastases.

Figure 5 shows the decreases in delta values in tissue-positive patients with metastases, with and without regression ( $p<0.0003)$. A PPV of $100 \%$ is seen at a delta decrease of at least $77 \mathrm{ng} / \mathrm{mL}$, incorrectly classifying 6 of 18 patients.

Figure $6 A$ and $B$ shows seven patients that illustrate the overall findings from Figures $3-5$. These show increases with disease progression, and decreases following response to targeted treatment (tissue-

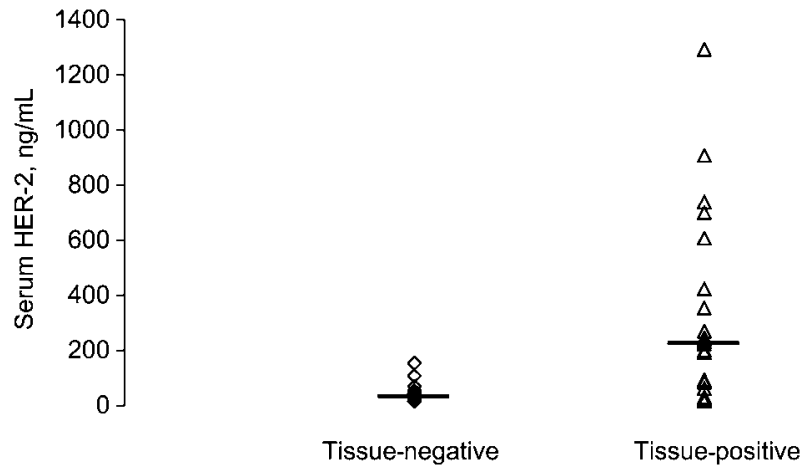

Figure 1 Serum HER-2 maximum values in tissue IHC/FISH negative $(n=69)$ and positive $(n=35)$ patients $(\mathrm{p}<0.0000001)$.

The highest values for serum HER-2 were seen in IHC-tissue positive patients. Three serum HER-2 values between $3300 \mathrm{ng} / \mathrm{mL}$ and $14,000 \mathrm{ng} / \mathrm{mL}$ from patients with positive tissue not shown.

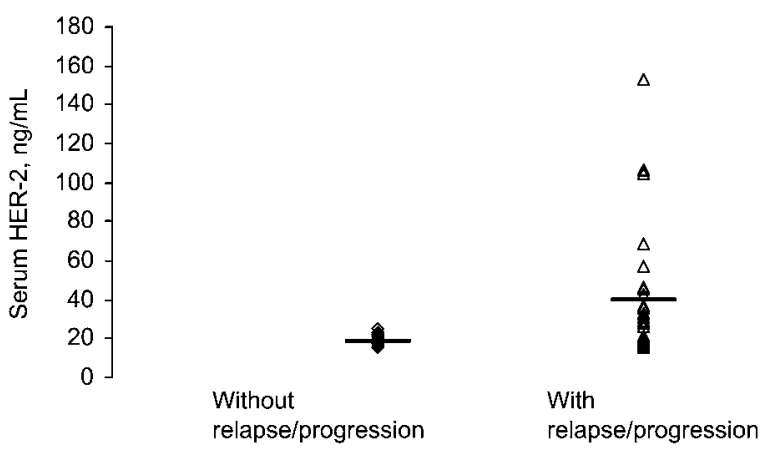

Figure 2 Maximum serum HER-2 values in 69 patients who were serum HER-2 positive but tissue HER-2 negative, patients without $(n=40)$ or with relapse/progression $(n=29)$ $(\mathrm{p}<0.00004)$.

In patients negative for HER-2 in tissue and with clinical relapse or progression, serum HER-2 levels were higher than in patients without relapse or progression. 


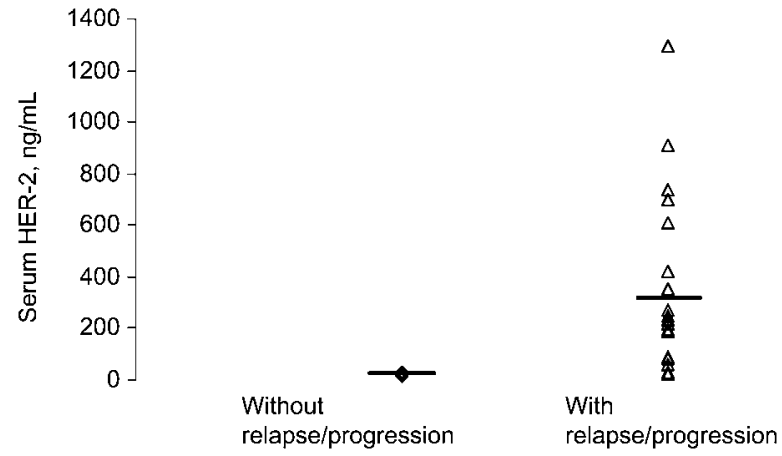

Figure 3 Maximum serum HER-2 values in 35 patients who were serum HER-2 positive, tissue HER-2 positive, in patients without $(n=10)$ or with relapse/progression $(n=25)$.

Three tissue-positive serum HER-2 values between 3300 $\mathrm{ng} / \mathrm{mL}$ and $14,000 \mathrm{ng} / \mathrm{mL}$ are not shown $(\mathrm{p}<0.00003)$.

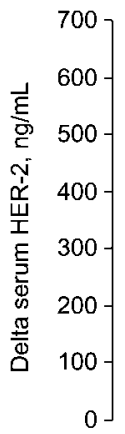

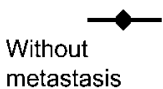

Figure 4 Positive delta values of serum HER-2 are shown for tissue-positive patients without $(n=10)$ or with progression to metastases $(n=25)(p<0.0003)$.

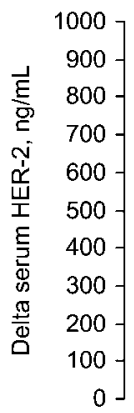

厽
$\Delta$
$\Delta$

Without regression
$\Delta$
$\Delta$
$\Delta$

$\Delta$

$\Delta$

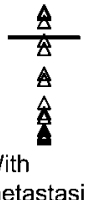

With

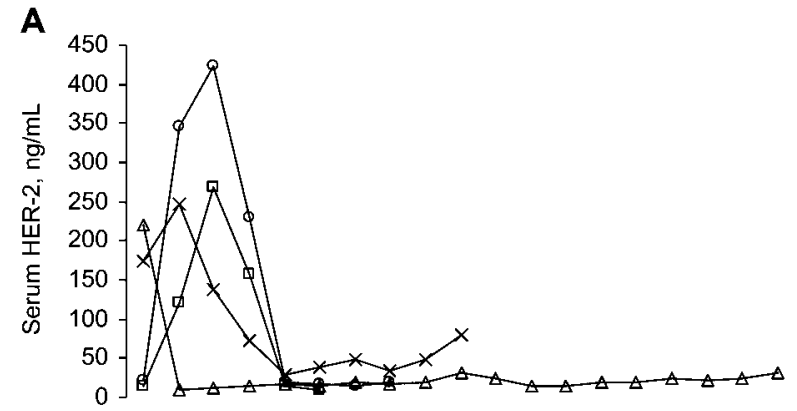

B

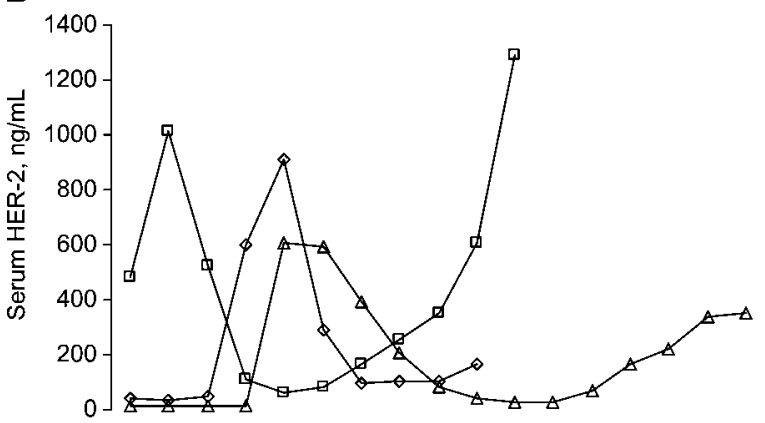

Figure 6 Serum HER-2 changes in four patients with clinical response and regression in metastases.

Serum HER-2 increases in relation to relapse in form of metastases and decrease in relation to response to therapy and regression (A). Serum HER-2 changes in three patients showing response to therapy and primary regression of metastases but secondary progression. Serum HER-2 increases to high levels in relation to relapse in form of metastases, decrease in relation to response to therapy and regression but increase again in relation to progression (B). The different symbols differentiate between patients and represent the time of blood sample.

\section{Discussion}

The primary aim of this project was to investigate the value of increased serum HER-2 concentrations for the follow-up of all surgically treated breast cancer patients, as well as patients treated previously and followed routinely by the Department of Oncology.

This design could not establish sensitivity and specificity for relapse or progression to metastases. Only the predictive value of a positive test, and the test performance for measuring treatment effects when serum HER-2 was positive in both tissue-positive and tissue-negative patients could be investigated. Patients with negative tissue HER-2 had as great a risk of developing positive serum HER-2 as did tissuepositive (69/437 and 35/206) ( $p=0.74)$.

This finding is surprising, considering the general opinion that only tissue-positive patients would develop serum positivity, unless primary tissue classification was erroneous, or conversion from non-amplified cancer cells to amplified had taken place. In our study, IHC/FISH was performed in both primary tumor and metastases in two patients; both were negative.

However, our data show that breast cancer, previously diagnosed as tissue-negative, reach serum HER-2 concentrations of maximum $200 \mathrm{ng} / \mathrm{mL}$, mean $27.3 \mathrm{ng} / \mathrm{mL}$. Tissue-positive patients achieve maxi-

Figure $8 \mathrm{~A}$ and $\mathrm{B}$ shows details in tissue-negative patients responding or not to treatment. 


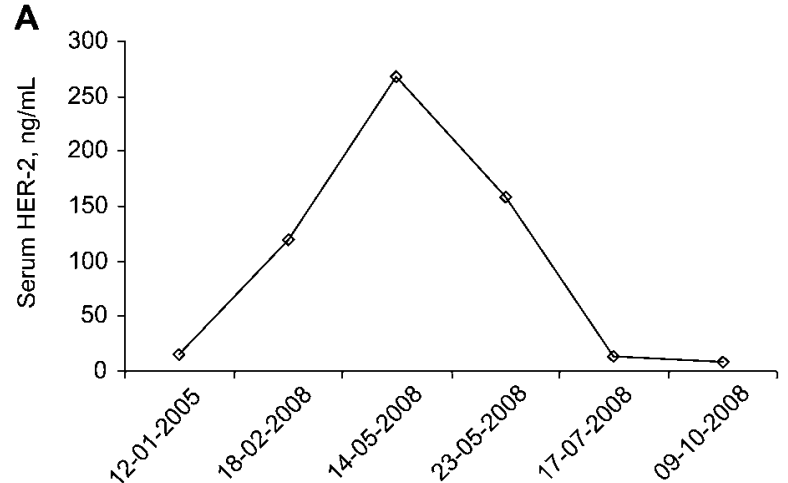

B
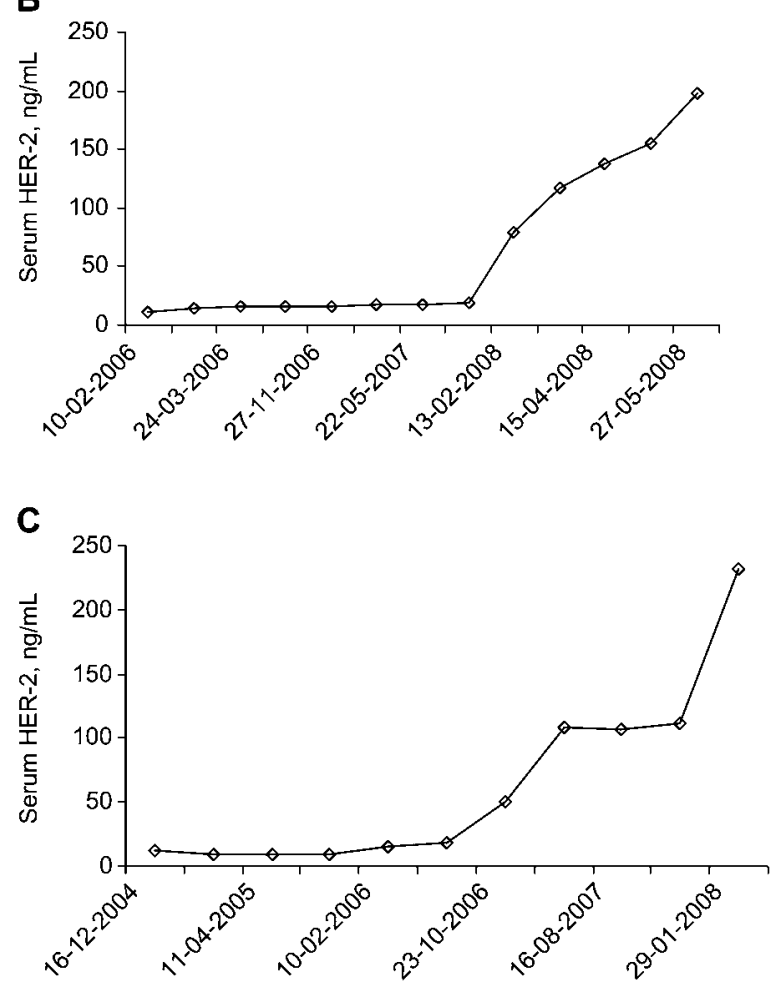

Figure 7 Details from tissue-positive patients responding or not to treatment.

(A) Details from a 59-year-old woman. Surgery 2001. Tissue HER-2 positive. Nine series FEC. Radiotherapy. August 2007 project medicine Lapatinib or placebo, adjuvant. CT 30.04.08 showed mediastinal and lung metastases. Received 5 series Trastuzumab-Paclitaxel (15.05.08-08.08.08). Regression of metastases on CT July 2008. (B) Details from a 57 -year-old woman. Surgery 2005. Tissue HER-2 positive. Seven series FEC followed by Tamoxifen, adjuvant. Relapse detected March 2008 when CT showed liver and lung metastases. Three series Trastuzumab-Vinorelbine (28.03.08-14.05.08). May 2008 progression. (C) Details from a 55 -year-old woman. Surgery 2004. Tissue HER-2 positive. Seven series FEC. Radiotherapy, adjuvant followed by Trastuzumab (10.02.06-27.12.06) but in spite of that lung metastases on CT 29.12.06. Trastuzumab-Docetaxel. March 2007 progression. Changed to Trastuzumab/Vinorelbine, progression, changed to Capecitabine, progression.

mum concentrations of $14,000 \mathrm{ng} / \mathrm{mL}$, mean 224.8 $\mathrm{ng} / \mathrm{mL}(\mathrm{p}<0.0000001)$. We do not believe that the explanation is either misdiagnosis or conversion. If this was the case, the serum HER-2 in tissue-negative patients would have been as high as in tissue-positive patients. Rather, the moderately increased concentra-
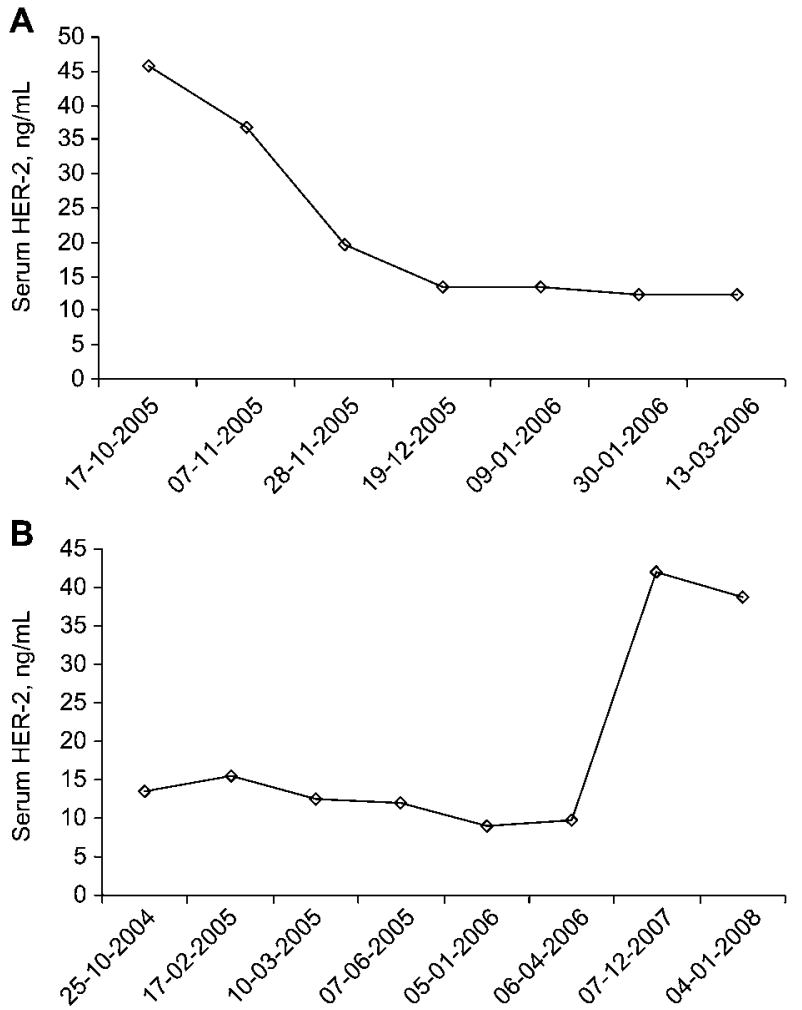

Figure 8 Details from tissue-negative patients responding or not to treatment.

(A) Details from a 45-year-old woman. Surgery February 2002. Local relapse June 2004. Tissue HER-2 negative. September 2005 bone metastases. Docetaxel-Capecitabine from November 2005 to March 2006. Regression on CT 15.12.05. (B) Details from a 70-year-old woman. Locally advanced breast cancer. Five series FEC (01.10.04-26.01.05) with little regression. Five series Docetaxel (18.02.05-19.05.05) with big regression, surgery 09.06.05. Tissue HER-2 negative. Relapse in form of liver, lung and bone metastases November 2007. Capecitabine, response $=$ no change.

tions reflect dissemination of cancer, which is HER-2 negative, but with an increased tumor load. However, it will be necessary to perform IHC/FISH on all metastases to clarify this.

It has been suggested that inflammation, infection or liver disease could slightly increase serum HER-2. However, we have found no publications to document this, and this was not seen in our patients as a general finding. However, for the tissue-positive and negative patients without metastases, 11 had slightly increased lactate dehydrogenase (LDH), none with increased C-reactive protein (CRP), and seven with increased alanine transaminase (ALT) $(n=50)$.

Further, the large difference in serum HER-2 concentrations in tissue-positive and tissue-negative patients shows that even low values above $20 \mathrm{ng} / \mathrm{mL}$ in tissue-negative patients should be taken seriously. Also, a concentration of $50 \mathrm{ng} / \mathrm{mL}$ in tissue-negative patients may reflect a metastatic burden corresponding to a level 5-10 times as high in tissue-positive patients.

Thus, there is also value in following tissue-negative patients with serum HER-2 measurements as this 


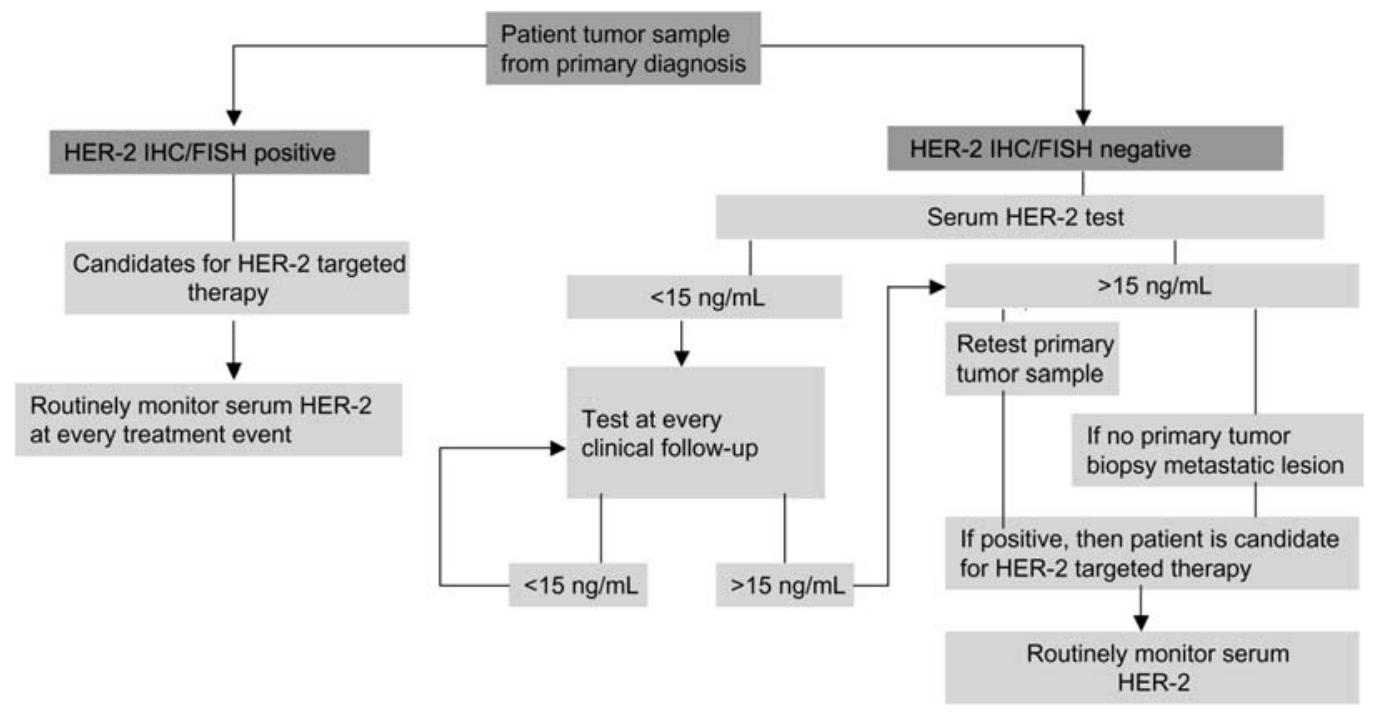

Figure 9 Proposal for serum HER-2 test algorithm.

detects recurrence or metastases with an acceptable PPV (29 of $69=42 \%, 95 \% \mathrm{Cl}: 30-54$ ).

The design of this investigation only allows determination of the PPV of increased serum HER-2 concentration. Of the 149 serum HER-2 positive patients, 55 had progression or dissemination of disease at a cut-off of $15 \mathrm{ng} / \mathrm{mL}$, giving a PPV of $37 \%(95 \% \mathrm{Cl}$ : 29-45), sufficient to decide further clinical investigation. If the maximum value for patients without metastases ( $n=94,32 \mathrm{ng} / \mathrm{mL}$ ) is used for the cut-off threshold, the PPV is $100 \%$ (34/34, misclassifying 21 patients, 95\% Cl: 90\%-100\%). Repeating these calculations for the tissue-positive and negative group, the values were $32 \mathrm{ng} / \mathrm{mL}$ (misclassifying 5 patients) and $25 \mathrm{ng} / \mathrm{mL}$ (misclassifying 11 patients).

This shows that serum values for patients known to be tissue-positive should be evaluated differently than serum values determined in patients that are tissuenegative. A $100 \%$ PPV is reached with a cut-off threshold of $32 \mathrm{ng} / \mathrm{mL}$ and $25 \mathrm{ng} / \mathrm{mL}$, respectively. Though single determinations have value for detecting metastases, monitoring of patients at suitable time intervals yields further information as shown in Figures 6-8. As Figure 5 shows, there is an excellent correlation between CT-determined regression and decreases in serum HER-2. These findings are also shown for selected patients (Figure 6) and in detail for individual patients in relation to treatment (Figures 7 and 8). Thus, it is not only important to follow-up positive values, but also moderate continuous increases should be watched closely (Figure 7B and C).

Other authors have reported similar finding. Esteva and colleagues (8) evaluated serum HER-2 in 30 women with positive tissue HER-2 MBC who were undergoing weekly Docetaxel and Trastuzumab therapy. They found that changes in serum HER-2 concentrations correlated well with the clinical course. Kong and colleagues (9) evaluated 195 patients with MBC and found that the mean serum HER-2 in the tissue-negative group was significantly lower than concentrations in the tissue-positive group: $22.2 \mu \mathrm{g} / \mathrm{L}$ vs. $363 \mu \mathrm{g} / \mathrm{L}$.
In a review, Carney and colleagues (10) described that some women with tissue HER-2 negative tumors developed increased serum HER-2 in metastatic disease. These findings were originally observed by Kandl et al. (11) and Molina et al. (12). Kandl and colleagues reported that some patients who were negative for tissue HER-2 developed extremely high serum HER-2 concentrations during MBC, and that increasing concentrations correlated with progression of disease.

Gancberg and colleagues (13) compared HER-2 status in primary breast cancer with corresponding distant metastatic sites from 107 patients. They found similar degrees of amplification (25\% and $24 \%$ ) and over expression (13\% and 19\%). Zidan and colleagues (14) found concordance in $86 \%$ of patients.

Carney and colleagues in another review (4) concluded that one potential clinical use of serum HER-2 was to identify patients with an elevated serum HER2 but negative tissue HER-2 because this could be the reason to re-evaluate the original or a metastatic tumor by IHC or FISH. They also concluded that the most probable reason for a patient to be found to be HER-2 negative is that the patient's tumor has $<10 \%$ $3+$ positive cells required to be considered HER-2 tissue-positive. However, it is likely that there are enough HER-2 positive cells in the primary tumor to generate HER-2 positive MBC.

Luftner and colleagues (15) recommend that patients with HER-2 positive tumors be followed at 3-6-month intervals with serial monitoring of serum HER-2 concentrations to detect relapse. They also concluded that determination of serum HER-2 is not likely to provide clinically useful information for those patients found to be tissue HER-2 negative. However, they did recommend that the first measurement of serum HER-2 be obtained at the time of relapse. This is in contrast to our findings. We found the same number of patients with positive serum HER-2 in the tissue-negative and the tissue-positive group.

Recently, Ardavanis and colleagues (16) treated 22 tissue-negative patients with serum HER-2 concentra- 
tions $\geq 15 \mathrm{ng} / \mathrm{mL}$ with Trastuzumab and Taxane. These patients had previously failed at least two lines of Anthracycline- and Taxane-based regimens. They observed minor response in five patients and stable disease in 11.

Recently, Suhail and colleagues (17) retrospectively analyzed individual pooled data from 307 patients with MBC treated with first line Trastuzumab-based therapy. They concluded that patients who did not achieve a significant decline ( $\geq 20 \%$ ) in serum HER-2 concentrations had decreased benefit from Trastuzumab-based therapy.

An important finding is that increases in serum HER-2 can detect recurrence in form of metastases or recurrence at an earlier time, before clinical methods. The lead-time of serum HER-2 increases prior to detection of recurrence could be determined in ten tissue-positive patients at 3-24 months (mean 11.3 months). If the decision to treat with targeted therapy, including Trastuzumab, based on statistically significant increases in serum HER-2 was taken earlier, more patients may be expected to survive longer. Only controlled trials can verify this.

While waiting for control trials to establish recommendations for the use of serum HER-2, we recommend the use of an algorithm as shown in Figure 9 for the detection of recurrence.

Also, the possible value of combining relative delta values of serum HER-2 concentrations as percent increases from base levels, or including CA 15-3 and CEA, should be investigated.

\section{Conflict of interest statement}

None of the author has any financial or other conflict of interests. None has been or is presently employed or supported by any company.

\section{Acknowledgements}

Test kits used for HER-2 serum measurements were provided by Siemens Health Care Diagnostics Inc. The authors thank the laboratory technologists Sara Egsgaard and Camilla Davidsen (Department of Clinical Biochemistry, Lillebaelt Hospital, Vejle, Denmark) for excellent work. The Research Fund at Vejle Hospital financed this work.

\section{References}

1. Olsen DA, Ostergaard B, Bokmand S, Wamberg PA, Jakobsen EH, Brandslund I. HER-2 protein concentrations in breast cancer cells increase before immunohistochemical and fluorescence in situ hybridization analysis turn positive. Clin Chem Lab Med 2007;45:177-82.

2. Slamon DJ, Clark GM, Wong SG, Levin WJ, Ullrich A, McGuire WL. Human breast cancer: correlation of relapse and survival with amplification of the HER-2/neu oncogene. Science 1987;235:177-82.

3. Zabrecky JR, Lam T, McKenzie SJ, Carney W. The extracellular domain of $\mathrm{p} 185 / \mathrm{neu}$ is released from the surface of human breast carcinoma cells, SK-BR-3. J Biol Chem 1991;266:1716-20.

4. Carney WP, Leitzel K, Ali S, Neumann R, Lipton A. HER$2 /$ neu diagnostics in breast cancer. Breast Cancer Res 2007;9:207.

5. Therasse P, Arbuck SG, Eisenhauer EA, Wanders J, KapIan RS, Rubinstein $L$, et al. New guidelines to evaluate the response to treatment in solid tumors. European Organization for Research and Treatment of Cancer, National Cancer Institute of the United States, National Cancer Institute of Canada. J Natl Cancer Inst 2000; 92:205-16.

6. Gehan EA, Tefft MC. Will there be resistance to the RECIST (Response Evaluation Criteria in Solid Tumors)? J Natl Cancer Inst 2000;92:179-81.

7. Gerhardt W, Keller H. Evaluation of test data from clinical studies. I. Terminology, graphic interpretation, diagnostic strategies, and selection of sample groups. II. Critical review of the concepts of efficiency, receiver operated characteristics (ROC), and likelihood ratios. Scand J Clin Lab Invest Suppl 1986;181:1-74.

8. Esteva FJ, Valero V, Booser D, Guerra LT, Murray JL, Pusztai $L$, et al. Phase II study of weekly docetaxel and trastuzumab for patients with HER-2-overexpressing metastatic breast cancer. J Clin Oncol 2002;20:1800-8.

9. Kong S-Y, Nam BH, Lee KS, Kwon Y, Lee ES, Seong MW, et al. Predicting tissue HER2 status using serum HER2 levels in patients with metastatic breast cancer. Clin Chem 2006;52:1510-5.

10. Carney WP, Neumann R, Lipton A, Leitzel K, Ali S, Price CP. Potential clinical utility of serum HER-2/neu oncoprotein concentrations in patients with breast cancer. Clin Chem 2003;49:1579-98.

11. Kandl H, Seymour L, Bezwoda WR. Soluble c-erbB-2 fragment in serum correlates with disease stage and predicts for shortened survival in patients with earlystage and advanced breast cancer. Br J Cancer 1994;70: 739-42.

12. Molina R, Jo J, Filella X, Zanon G, Pahisa J, Munoz M, et al. C-erbB-2 oncoprotein in the sera and tissue of patients with breast cancer. Utility in prognosis. Anticancer Res 1996;16:2295-300.

13. Gancberg D, Di LA, Cardoso F, Rouas G, Pedrocchi M, Paesmans M, et al. Comparison of HER-2 status between primary breast cancer and corresponding distant metastatic sites. Ann Oncol 2002;13:1036-43.

14. Zidan J, Dashkovsky I, Stayerman C, Basher W, Cozacov C, Hadary A. Comparison of HER-2 overexpression in primary breast cancer and metastatic sites and its effect on biological targeting therapy of metastatic disease. $\mathrm{Br} \mathrm{J}$ Cancer 2005;93:552-6.

15. Luftner D, Luke C, Possinger K. Serum HER-2/neu in the management of breast cancer patients. Clin Biochem 2003;36:233-40.

16. Ardavanis $A$, Kountourakis $P$, Kyriakou $F$, Malliou $S$, Mantzaris I, Garoufali A, et al. Trastuzumab plus paclitaxel or docetaxel in HER-2-negative/HER-2 ECD-positive anthracycline- and taxane-refractory advanced breast cancer. Oncologist 2008;13:361-9.

17. Ali SM, Carney WP, Esteva FJ, Fornier M, Harris L, Kostler WJ, et al. Serum HER-2/neu and relative resistance to trastuzumab-based therapy in patients with metastatic breast cancer. Cancer 2008;113:1294-301. 